\title{
Loci of agreement and deviations from the Mirror Principle in Hungarian verbs
}

\section{Kevin Kwong*}

Abstract. In this revised account of Hungarian verbal agreement, I propose that the language's locus of subject agreement is not T, unlike in current Minimalist analyses, but Pred (or Asp), just above direct object agreement in $v$. Furthermore, the surface linear order of affixes (stem - tense/mood - object agreement - subject agreement) does not conform to the hierarchical order of syntactic heads ( $\mathrm{V}<v$ $<$ Pred $<\mathrm{T}<\mathrm{M}$ ), thus violating the Mirror Principle, because local dislocation in postsyntactic morphology adjusts the initial linearization of the heads.

Keywords. Hungarian; agreement; affix order; Mirror Principle; local dislocation

1. Introduction. According to the Mirror Principle (Baker 1985), the linear order of affixes should reflect the hierarchical order of the syntactic heads that they realize. The current Minimalist framework (Chomsky 2000) associates direct object (O) and subject (S) agreement with $v$ and $\mathrm{T}$, respectively, in the hierarchy $\mathrm{V}<v<\mathrm{T}<\mathrm{M} .{ }^{1}$ Yet this conflicts with the Hungarian verb's linear order $\Sigma-\tau / \mu-\pi_{\mathrm{O}}-\pi_{\mathrm{S}^{-}} \#_{\mathrm{S}}$, in which all agreement suffixes follow (not precede) tense/mood. After presenting the data $(\S 2)$, I review previous approaches to the puzzle $(\S 3)$, and outline a new analysis ascribing the deviations to postsyntactic local dislocation (\$4). Next I offer a phasal, synchronic reason for preferring Pred to $\mathrm{T}$ as the S-agreement locus ( $\$ 5$ ), examine diachronic evidence from Old Hungarian (\$6), and explore implications for infinitives (§7), before summarizing the findings ( $\$ 8)$. Throughout this paper, I adopt the model of grammar in (1), which limits morphological processes to post-syntax between Spellout and PF:

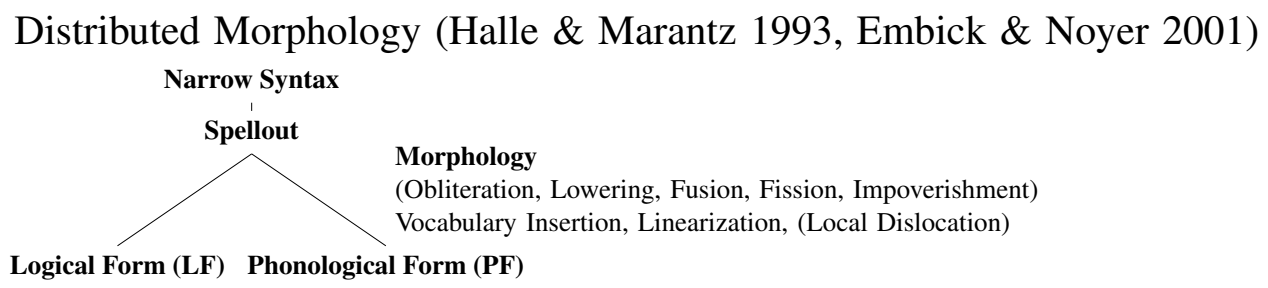

MORPHEMES are abstract feature bundles on hierarchical syntactic heads. In morphology, morphemes acquire phonological content during vocabulary insertion and become linearized. Those with vocabulary items (null or overt exponents) are EXPRESSIBLE; all others are inexpressible.

2. Data. Hungarian transitive verbs inflect for the NON-PHI features of tense $\tau$ and mood $\mu$, and PHI features of subject person $\pi_{\mathrm{S}}$, subject number $\#_{\mathrm{S}}$, and direct object person $\pi_{\mathrm{O}}$ agreement. Each person and number represents a set of privative subfeatures. ${ }^{2}$ The combinations of $\tau$ and $\mu$ are illustrated here for vár 'wait' with $2 \mathrm{PL}(\mathrm{S}) \rightarrow 1 \mathrm{SG} / 3 \mathrm{SG}(\mathrm{O}) .^{3}$

\footnotetext{
* Many thanks to my consultants for their judgments, and Miloje Despić, Sarah Murray, Eszter Ótott-Kovács, Carol Rounds, and John Whitman for their comments. Author: Kevin Kwong, Cornell University (kk936@cornell.edu). ${ }^{1}$ Non-Leipzig abbreviations: \# number; 0 no person; Asp/ $\alpha$ aspect (head/feature); C complementizer; CV coverb; D determiner; GRP group; IDV individual; $i$ interpretable; M/ $\mu$ mood (head/feature); N noun; NN no number; NNe nonneutral; Num numeral; PAR participant; Pred predication; PSM possessum; PSR possessor; REF referring expression; SPK speaker; T/ $\tau$ tense (head/feature); $u$ uninterpretable; V verb; $\kappa$ case; $\pi$ person; $\Sigma$ stem.

${ }^{2}$ Based on Harley \& Ritter (2002) and Bárány (2018), the persons are: $1 \pi\{$ REF, PAR, SPK $\} ; 2 \pi\{$ REF, PAR $\} ; 3 \pi$ $\{\mathrm{REF}\} ; 0 \pi$ (no person) \{\} . The numbers are: plural $\{$ IDV, GRP $\}$; singular $\{$ IDV $\}$; NN (no number) \{\} . Subset and superset relationships between non-empty (i.e., $1 / 2 / 3 \pi) \pi_{\mathrm{S}}$ and $\pi_{\mathrm{O}}$ determine person hierarchy effects: see n6.

${ }^{3}$ Underlying forms given below surface forms rely on Abondolo's (1988) morphophonological rules, but without
} 
ERARCHY $1>2>3$, by rearranging the non-past indicatives by combinations of $\mathrm{S}$ and $\mathrm{O} .^{6}$

\begin{tabular}{|c|c|c|c|c|}
\hline $\mathrm{S}$ & $\begin{array}{l}\mathrm{CA}_{\mathrm{I}} \\
\text { INTR }\end{array}$ & $\begin{array}{c}\mathrm{CA}_{\mathrm{T}} \\
1 \rightarrow 0 ; 1 \mathrm{PL} \rightarrow 2 ; \\
2 \rightarrow 1 / 0 ; 3 / 0 \rightarrow 1 / 2 / 0\end{array}$ & $\begin{array}{c}\mathrm{CB} \\
1 / 2 / 3 / 0 \rightarrow 3\end{array}$ & $\begin{array}{c}\mathrm{CC} \\
1 \mathrm{sG} \rightarrow 2\end{array}$ \\
\hline \multirow{2}{*}{$1 \mathrm{SG}$} & vár-ok- $\varnothing$ & vár- $\varnothing-o k-\varnothing$ & vár- $\varnothing-$ om- $\varnothing$ & vár-l-ak-Ø \\
\hline & $-\mathrm{Ok} / \mathrm{Om}-\varnothing$ & $-\varnothing-\mathrm{Ok} / \mathrm{Om}-\varnothing$ & $-\varnothing-O m-\varnothing$ & $-\mathrm{Ol}-\mathrm{Ok}-\varnothing$ \\
\hline \multirow{2}{*}{$1 \mathrm{PL}$} & vár-un-k & vár- $\varnothing-u n-k$ & vár-j-u-k & \multirow{2}{*}{ - } \\
\hline & -Un-k & $-\varnothing-U n-k$ & -iÁ-U-k & \\
\hline \multirow{2}{*}{$2 \mathrm{SG}$} & vár-sz- $\varnothing$ & vár- $\varnothing-s z-\varnothing$ & vár- $\varnothing-o d-\varnothing$ & \multirow{2}{*}{ 一 } \\
\hline & $-\mathrm{Ol} / \mathrm{sz}-\varnothing$ & $-\varnothing-01 / \mathrm{sz}-\varnothing$ & $-\varnothing-O d-\varnothing$ & \\
\hline \multirow{2}{*}{$2 \mathrm{PL}$} & vár-to-k & vár- $\varnothing-t o-k$ & vár-já-to-k & \multirow[b]{2}{*}{-} \\
\hline & $-\mathrm{tO}-\mathrm{k}$ & $-\varnothing-\mathrm{tO}-\mathrm{k}$ & -iÁ-tO-k & \\
\hline $3 \mathrm{SG} /$ & $v a ́ r-\varnothing-\varnothing$ & vár- $\varnothing-\varnothing-\varnothing$ & vár-ja- $\varnothing-\varnothing$ & \multirow{2}{*}{ - } \\
\hline 0SG & $-\varnothing / \mathrm{ik}-\varnothing$ & $-\varnothing-\varnothing / \mathrm{ik}-\varnothing$ & $-\mathrm{i} A ́-\varnothing-\varnothing$ & \\
\hline 3PL/ & vár-na-k & vár- $\varnothing-n a-k$ & vár-já- $\varnothing-k$ & \multirow{2}{*}{ 一 } \\
\hline OPL & $-n A-k$ & $-\varnothing-\mathrm{nA}-\mathrm{k}$ & $-\mathrm{iÁ}-\varnothing-\mathrm{k}$ & \\
\hline
\end{tabular}

\section{Table 1. Non-past indicative}

\begin{tabular}{|c|c|c|c|c|}
\hline $\mathrm{S}$ & $\begin{array}{l}\mathrm{CA}_{\mathrm{I}} \\
\text { INTR }\end{array}$ & $\begin{array}{c}\mathrm{CA}_{\mathrm{T}} \\
1 \rightarrow 0 ; 1 \mathrm{PL} \rightarrow 2 ; \\
2 \rightarrow 1 / 0 ; 3 / 0 \rightarrow 1 / 2 / 0\end{array}$ & $\begin{array}{c}\mathrm{CB} \\
1 / 2 / 3 / 0 \rightarrow 3\end{array}$ & $\begin{array}{c}\mathrm{CC} \\
1 \mathrm{sG} \rightarrow 2\end{array}$ \\
\hline $1 \mathrm{SG}$ & $\begin{array}{l}\text { vár-ja-k- } \varnothing \\
-\mathrm{jA}-\mathrm{Ok}-\varnothing\end{array}$ & $\begin{array}{l}\text { vár-ja- } \varnothing-k-\varnothing \\
-\mathrm{j} A-\varnothing-\mathrm{Ok}-\varnothing\end{array}$ & $\begin{array}{l}\text { vár-ja- } \varnothing-m-\varnothing \\
-\mathrm{j} A-\varnothing-O m-\varnothing\end{array}$ & $\begin{array}{l}\text { vár-ja-l-ak- } \varnothing \\
\text {-jA-Ol-Ok- } \varnothing\end{array}$ \\
\hline $1 \mathrm{PL}$ & $\begin{array}{l}\text { vár-j-un-k } \\
\text {-jA-Un-k }\end{array}$ & $\begin{array}{l}\text { vár-j-Ø-un-k } \\
-\mathrm{j} A-\varnothing-\mathrm{Un}-\mathrm{k}\end{array}$ & $\begin{array}{c}\text { vár-j-u-k } \\
-\mathrm{jA}-\mathrm{iÁ}-\mathrm{U}-\mathrm{k}\end{array}$ & - \\
\hline $\begin{array}{l}2 \mathrm{SG} \\
\text { (short } \\
\text { forms) }\end{array}$ & $\begin{array}{l}\text { vár-já-l- } \varnothing \\
-\mathrm{jA}-\mathrm{O}-\varnothing \\
(v a r r-j-\varnothing-\varnothing) \\
-\mathrm{jA}-\varnothing-\varnothing\end{array}$ & 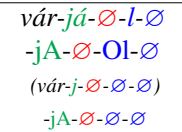 & $\begin{array}{c}\text { vár-ja- } \varnothing-d-\varnothing \\
-\mathrm{jA}-\varnothing-\mathrm{Od}-\varnothing \\
(v a ̂ r-\varnothing-d-\varnothing) \\
-\mathrm{jA}-\varnothing-\mathrm{d}-\varnothing\end{array}$ & - \\
\hline $2 \mathrm{PL}$ & $\begin{array}{c}\text { vár-ja-to-k } \\
-\mathrm{jA}-\mathrm{tO}-\mathrm{k}\end{array}$ & $\begin{array}{c}\text { vár-ja- } \varnothing-t o-k \\
-\mathrm{j} A-\varnothing-\mathrm{tO}-\mathrm{k}\end{array}$ & $\begin{array}{l}\text { vár-j-á-to-k } \\
-\mathrm{jA}-\mathrm{iÁ}-\mathrm{tO}-\mathrm{k}\end{array}$ & - \\
\hline $\begin{array}{l}3 \mathrm{SG} / \\
0 \mathrm{SG}\end{array}$ & $\begin{array}{l}\text { vár-j-on- } \varnothing \\
-\mathrm{j} A-O n-\varnothing\end{array}$ & $\begin{array}{l}\text { vár-j- } \varnothing-\text { on- } \varnothing \\
-\mathrm{j} A-\varnothing-O n-\varnothing\end{array}$ & $\begin{array}{l}\text { vár-j-a- } \varnothing-\varnothing \\
-j A-i A ́-\varnothing-\varnothing\end{array}$ & - \\
\hline $\begin{array}{l}\text { 3PL/ } \\
\text { 0PL }\end{array}$ & $\begin{array}{c}\text { vár-ja-na-k } \\
\text {-jA-nA-k }\end{array}$ & $\begin{array}{c}\text { vár-ja- } \varnothing-n a-k \\
-\mathrm{j} A-\varnothing-\mathrm{nA}-\mathrm{k}\end{array}$ & $\begin{array}{l}\text { vár-j-á-Ø-k } \\
-\mathrm{jA}-\mathrm{i} \hat{\mathrm{A}}-\varnothing-\mathrm{k}\end{array}$ & - \\
\hline
\end{tabular}

Table 3. Non-past subjunctive (SBJV: $-j A)$

\begin{tabular}{|c|c|c|}
\hline $\mathrm{S}$ & \multicolumn{2}{|c|}{ 1/2/3/0/INTR } \\
\hline $1 \mathrm{SG}$ & vár-n-om- $\varnothing$ & $-\mathrm{ni}_{2}-\mathrm{Om}-\varnothing$ \\
\hline 1PL & vár-n-un-k & -ni ${ }_{2}$-Un-k \\
\hline $2 \mathrm{SG}$ & vár-n-od- $\varnothing$ & $-\mathrm{ni}_{2}-\mathrm{Od}-\varnothing$ \\
\hline $2 \mathrm{PL}$ & vár-n-oto- $k$ & $-\mathrm{ni}_{2}-\mathrm{tO}-\mathrm{k}$ \\
\hline $\begin{array}{l}3 \mathrm{SG} / \\
0 \mathrm{SG}\end{array}$ & vár-ni(j)a- $\varnothing-\varnothing$ & -niiÁ- $\varnothing-\varnothing$ \\
\hline $\begin{array}{l}\text { 3PL/ } \\
\text { 0PL }\end{array}$ & vár-ni(j)-u-k & -niiÁ-U-k \\
\hline $\begin{array}{l}\text { ONN } \\
P R O\end{array}$ & vár-ni- $\varnothing-\varnothing$ & $-n i_{1}-\varnothing-\varnothing$ \\
\hline
\end{tabular}

Table 5. Infinitive (INF: $\left.-n i_{1} /-n i_{2} /-n i i A ́\right)$ $(j)$ is pronounced but unwritten (Abondolo 1988:261).

\begin{tabular}{|c|c|c|c|c|}
\hline $\mathrm{S}$ & $\begin{array}{l}\mathrm{CA}_{\mathrm{I}} \\
\text { INTR }\end{array}$ & $\begin{array}{c}\mathrm{CA}_{\mathrm{T}} \\
1 \rightarrow 0 ; 1 \mathrm{PL} \rightarrow 2 ; \\
2 \rightarrow 1 / 0 ; 3 / 0 \rightarrow 1 / 2 / 0\end{array}$ & $\begin{array}{c}\text { CB } \\
1 / 2 / 3 / 0 \rightarrow 3\end{array}$ & $\begin{array}{c}\mathrm{CC} \\
1 \mathrm{sG} \rightarrow 2\end{array}$ \\
\hline \multirow{2}{*}{$1 \mathrm{SG}$} & vár-ta-m- $\varnothing$ & vár-ta- $\varnothing-m-\varnothing$ & vár-ta- $\varnothing-m-\varnothing$ & 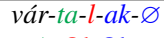 \\
\hline & $-\mathrm{ttA}-\mathrm{Om}-\varnothing$ & $-\mathrm{tt} A-\varnothing-\mathrm{Om}-\varnothing$ & -ttA- $\varnothing-\mathrm{Om}-\varnothing$ & -ttA-Ol-Ok- $\varnothing$ \\
\hline \multirow{2}{*}{$1 \mathrm{PL}$} & vár-t-un-k & vár-t- $\varnothing-u n-k$ & vár-t-u-k & \multirow{2}{*}{ 一 } \\
\hline & -ttA-Un-k & $-\mathrm{ttA}-\varnothing-\mathrm{Un}-\mathrm{k}$ & -ttA-iÁ-U-k & \\
\hline \multirow{2}{*}{$2 S G$} & vár-tá-l-Ø & vár-tá- $\varnothing-l-\varnothing$ & vár-ta- $\varnothing-d-\varnothing$ & \multirow{2}{*}{ - } \\
\hline & -ttA-Ol- $\varnothing$ & $-\mathrm{ttA}-\varnothing-\mathrm{Ol}-\varnothing$ & -ttA- $\varnothing-\mathrm{Od}-\varnothing$ & \\
\hline \multirow{2}{*}{$2 \mathrm{PL}$} & vár-ta-to-k & vár-ta- $\varnothing-t o-k$ & vár-t-á-to-k & \multirow{2}{*}{ 一 } \\
\hline & $-\mathrm{ttA}-\mathrm{tO}-\mathrm{k}$ & $-\mathrm{ttA}-\varnothing-\mathrm{tO}-\mathrm{k}$ & -ttA-iÁ-tO-k & \\
\hline $3 \mathrm{SG} /$ & vár-t- $\varnothing-\varnothing$ & vár-t- $\varnothing-\varnothing-\varnothing$ & vár-t-a- $\varnothing-\varnothing$ & \multirow{2}{*}{ - } \\
\hline OSG & $-\mathrm{tt} A-\varnothing-\varnothing$ & $-\operatorname{tt} A-\varnothing-\varnothing-\varnothing$ & -ttA-iÁ- $\varnothing-\varnothing$ & \\
\hline 3PL/ & vár-ta- $\varnothing-k$ & vár-ta- $\varnothing-\varnothing-k$ & $v a ́ r-t-a ́-\varnothing-k$ & \multirow{2}{*}{ - } \\
\hline OPL & $-\mathrm{tt} A-\varnothing-\mathrm{k}$ & $-\mathrm{ttA}-\varnothing-\varnothing-\mathrm{k}$ & $-\mathrm{tt} A-\mathrm{i} A ́-\varnothing-\mathrm{k}$ & \\
\hline
\end{tabular}

Table 2. Past indicative (PST: $-t t A)$

\begin{tabular}{|c|c|c|c|c|}
\hline$S$ & $\begin{array}{l}\mathrm{CA}_{\mathrm{I}} \\
\text { INTR }\end{array}$ & $\begin{array}{c}\mathrm{CA}_{\mathrm{T}} \\
1 \rightarrow 0 ; 1 \mathrm{PL} \rightarrow 2 ; \\
2 \rightarrow 1 / 0 ; 3 / 0 \rightarrow 1 / 2 / 0\end{array}$ & $\begin{array}{c}\text { CB } \\
1 / 2 / 3 / 0 \rightarrow 3\end{array}$ & $\begin{array}{c}\mathrm{CC} \\
1 \mathrm{sG} \rightarrow 2\end{array}$ \\
\hline $1 \mathrm{SG}$ & $\begin{array}{l}\text { vár-n-ék- } \varnothing \\
\text {-nÁ-ék- } \varnothing\end{array}$ & $\begin{array}{l}\text { vár-n- } \varnothing-e ́ k-\varnothing \\
\text {-nÁ- } \varnothing \text {-ék- } \varnothing\end{array}$ & $\begin{array}{l}\text { vár-ná- } \varnothing-m-\varnothing \\
\text {-nÁ- } \varnothing-O m-\varnothing\end{array}$ & $\begin{array}{l}\text { vár-ná-l-ak- } \varnothing \\
\text {-nÁ-Ol-Ok- } \varnothing\end{array}$ \\
\hline $1 \mathrm{PL}$ & $\begin{array}{l}\text { vár-ná-n-k } \\
\text {-nÁ-Un-k }\end{array}$ & $\begin{array}{l}\text { vár-ná- } \varnothing-n-k \\
\text {-nÁ- } \varnothing-U n-k\end{array}$ & $\begin{array}{l}\text { vár-ná- } \varnothing-n-k \\
\text {-nÁ- } \varnothing-U n-k\end{array}$ & - \\
\hline $2 \mathrm{SG}$ & 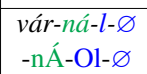 & $\begin{array}{l}\text { vár-ná- } \varnothing-l-\varnothing \\
\text {-nÁ- } \varnothing-\mathrm{O}-\varnothing\end{array}$ & $\begin{array}{l}\text { vár-ná- } \varnothing-d-\varnothing \\
\text {-nÁ- } \varnothing-O d-\varnothing\end{array}$ & - \\
\hline $2 \mathrm{PL}$ & $\begin{array}{c}\text { vár-ná-to-k } \\
\text {-nÁ-tO-k }\end{array}$ & $\begin{array}{c}\text { vár-ná- } \varnothing-t o-k \\
\text {-nÁ- } \varnothing-\mathrm{tO}-\mathrm{k}\end{array}$ & $\begin{array}{l}\text { vár-ná-to-k } \\
\text {-nÁ-iÁ-tO-k }\end{array}$ & - \\
\hline $\begin{array}{l}3 \mathrm{SG} / \\
0 \mathrm{SG}\end{array}$ & $\begin{array}{c}\text { vár-na- } \varnothing-\varnothing \\
\text {-nÁ- } \varnothing-\varnothing\end{array}$ & $\begin{array}{c}\text { vár-na- } \varnothing-\varnothing-\varnothing \\
\text {-nÁ- } \varnothing-\varnothing-\varnothing\end{array}$ & $\begin{array}{l}\text { vár-ná- } \varnothing-\varnothing \\
\text {-nÁ-iÁ- } \varnothing-\varnothing\end{array}$ & - \\
\hline $\begin{array}{l}3 \mathrm{PL} / \\
0 \mathrm{PL}\end{array}$ & $\begin{array}{c}\text { vár-ná-na-k } \\
\text {-nÁ-nA-k }\end{array}$ & $\begin{array}{c}\text { vár-ná- } \varnothing-n a-k \\
\text {-nÁ- } \varnothing-n A-k\end{array}$ & 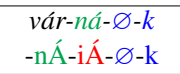 & - \\
\hline
\end{tabular}

Table 4. Non-past conditional (COND: $-n A ́)$

\begin{tabular}{|c|c|c|c|c|c|}
\hline 0 & 1 & 2 & 3 & 0 & INTR \\
\hline SG & - & 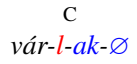 & $\begin{array}{c}\mathrm{B} \\
\text { vár- } \varnothing-\text { om- } \varnothing\end{array}$ & $\begin{array}{c}\mathrm{A}_{\mathrm{T}} \\
\text { vár- } \varnothing-o k-\varnothing\end{array}$ & $\begin{array}{c}\mathrm{A}_{\mathrm{I}} \\
\text { vár-ok- } \varnothing\end{array}$ \\
\hline PL & - & $\begin{array}{c}\mathrm{A}_{\mathrm{T}} \\
\text { vár- } \varnothing-u n-k\end{array}$ & $\begin{array}{c}\mathrm{B} \\
v a ́ r-j-u-k\end{array}$ & $\begin{array}{c}\mathrm{A}_{\mathrm{T}} \\
\text { vár- } \varnothing-u n-k\end{array}$ & $\begin{array}{c}\mathrm{A}_{\mathrm{I}} \\
\text { vár-un-k }\end{array}$ \\
\hline SG & $\begin{array}{c}\mathrm{A}_{\mathrm{T}} \\
\text { vár- } \varnothing-s z-\varnothing\end{array}$ & - & $\begin{array}{c}\mathrm{B} \\
v a ́ r-\varnothing-o d-\varnothing\end{array}$ & $\begin{array}{c}\mathrm{A}_{\mathrm{T}} \\
\text { vár- } \varnothing-s z-\varnothing\end{array}$ & $\underset{\text { vár-sz- } \varnothing}{\mathrm{A}_{\mathrm{I}}}$ \\
\hline & $\begin{array}{c}\mathrm{A}_{\mathrm{T}} \\
v a ́ r-\varnothing-t o-k\end{array}$ & - & $\begin{array}{c}\mathrm{B} \\
v a ́ r-j a ́-t o-k\end{array}$ & $\begin{array}{c}\mathrm{A}_{\mathrm{T}} \\
\text { vár- } \varnothing-\text {-to-k }\end{array}$ & $\begin{array}{c}\mathrm{A}_{\mathrm{I}} \\
\text { vár-to-k }\end{array}$ \\
\hline & $\begin{array}{c}\mathrm{A}_{\mathrm{T}} \\
v a ́ r-\varnothing-\varnothing-\varnothing\end{array}$ & $\begin{array}{c}\mathrm{A}_{\mathrm{T}} \\
v a ́ r-\varnothing-\varnothing-\varnothing\end{array}$ & $\begin{array}{c}\text { В } \\
v a ́ r-j a-\varnothing-\varnothing\end{array}$ & $\begin{array}{c}\mathrm{A}_{\mathrm{T}} \\
v a ́ r-\varnothing-\varnothing-\varnothing\end{array}$ & $\begin{array}{c}\mathrm{A}_{\mathrm{I}} \\
v a ́ r-\varnothing-\varnothing\end{array}$ \\
\hline & $\begin{array}{c}\mathrm{A}_{\mathrm{T}} \\
v a ́ r-\varnothing-n a-k\end{array}$ & $\begin{array}{c}\mathrm{A}_{\mathrm{T}} \\
v a ́ r-\varnothing-n a-k\end{array}$ & vár-já-Ø-k & $\begin{array}{c}\mathrm{A}_{\mathrm{T}} \\
\text { vár- } \varnothing-n a-k\end{array}$ & $\begin{array}{c}\mathrm{A}_{\mathrm{I}} \\
\text { vár-na-k}\end{array}$ \\
\hline & $\begin{array}{c}\mathrm{A}_{\mathrm{T}} \\
\text { vár- } \varnothing-\varnothing-\varnothing\end{array}$ & $\begin{array}{c}\mathrm{A}_{\mathrm{T}} \\
\text { vár }-\varnothing-\varnothing-\varnothing\end{array}$ & $\begin{array}{c}\mathrm{B} \\
v a ́ r-j a-\varnothing-\varnothing\end{array}$ & $\begin{array}{c}\mathrm{A}_{\mathrm{T}} \\
v a ́ r-\varnothing-\varnothing-\varnothing\end{array}$ & $\begin{array}{c}\mathrm{A}_{\mathrm{I}} \\
v a ́ r-\varnothing-\varnothing\end{array}$ \\
\hline & $\begin{array}{c}\mathrm{A}_{\mathrm{T}} \\
v a ́ r-\varnothing-n a-k\end{array}$ & $\begin{array}{c}\mathrm{A}_{\mathrm{T}} \\
v a ́ r-\varnothing-n a-k\end{array}$ & $\begin{array}{c}\mathrm{B} \\
v a ́ r-j a ́-\varnothing-k\end{array}$ & $\begin{array}{c}\mathrm{A}_{\mathrm{T}} \\
v a ́ r-\varnothing-n a-k\end{array}$ & $\begin{array}{c}\mathrm{A}_{\mathrm{I}} \\
v a ́ r-n a-k\end{array}$ \\
\hline
\end{tabular}

Table 6. Person hierarchy effects (inside box)

suffix /- $\varnothing /$-iÁ/ used in possessive DPs (kalap- $\varnothing-\varnothing$-om- $\varnothing$ hat-PSM-SG.PSM-1.PSR-SG.PSR 'my hat'; kalap-ja- $\varnothing-\varnothing-$ $\varnothing$ hat-PSM-SG.PSM-3.PSR-SG.PSR 'his/her hat'). INF /-niiÁ/ and PSM /-iÁ/ are related to $3 \pi_{\mathrm{O}}$ suffix /-iÁ/ in CB; all display co-occurrence constraints with $1 \pi /-\mathbf{O m} /$ and $2 \pi /$ /Od/ for $1 \mathrm{SG}$ and $2 \mathrm{SG} \pi_{\mathrm{S}} / \pi_{\mathrm{PSR}}$ (see n6; den Dikken 2018). ${ }^{6} \pi_{\mathrm{O}}$ is encoded in direct contexts (unshaded in box; $\mathrm{S} \geq \mathrm{O} ; \pi_{\mathrm{S}} \supseteq \pi_{\mathrm{O}}$ ), except $1 \mathrm{PL} \rightarrow 2$ and $1 \mathrm{sG} / 2 \mathrm{SG} \rightarrow 3$, by overt $\mathrm{CB} / \mathrm{CC}$ suffixes; and in inverse ones (shaded; $\mathrm{S}<\mathrm{O} ; \pi_{\mathrm{S}} \subset \pi_{\mathrm{O}}$ ) by null $\mathrm{CA}_{\mathrm{T}}$ suffixes. With SG $\mathrm{S}$, the $3 \pi_{\mathrm{O}}$ suffix is $-\varnothing$ in $1 \mathrm{SG} / 2 \mathrm{SG} \rightarrow 3\left(\mathrm{~S}>\mathrm{O} ; \pi_{\mathrm{S}} \supset \pi_{\mathrm{O}}\right)$; and $/-i \boldsymbol{A} /$ in $3 \mathrm{SG} \rightarrow 3\left(\mathrm{~S}=\mathrm{O} ; \pi_{\mathrm{S}}=\pi_{\mathrm{O}}\right)$, a form banned with $1 \pi /-O \mathrm{~m} /$ or $2 \pi /-O d /$. 
3. Previous approaches. $\tau$ and $\mu$ reside naturally on $\mathrm{T}$ and $\mathrm{M}$, respectively, but different loci have been proposed for the agreement features, with varying fidelity to the Mirror Principle.

EARLY MINIMALISM identifies O- and S-agreement with AgrO and AgrS, respectively, the heads of agreement phrases whose position is language-contingent. In Hungarian, AgrSP dominates AgrOP, MP, and TP (Bartos 2000, É. Kiss 2002):

(7) Early Minimalism: derivation of (4), $2 \mathrm{PL} \rightarrow 3 \mathrm{SG}$

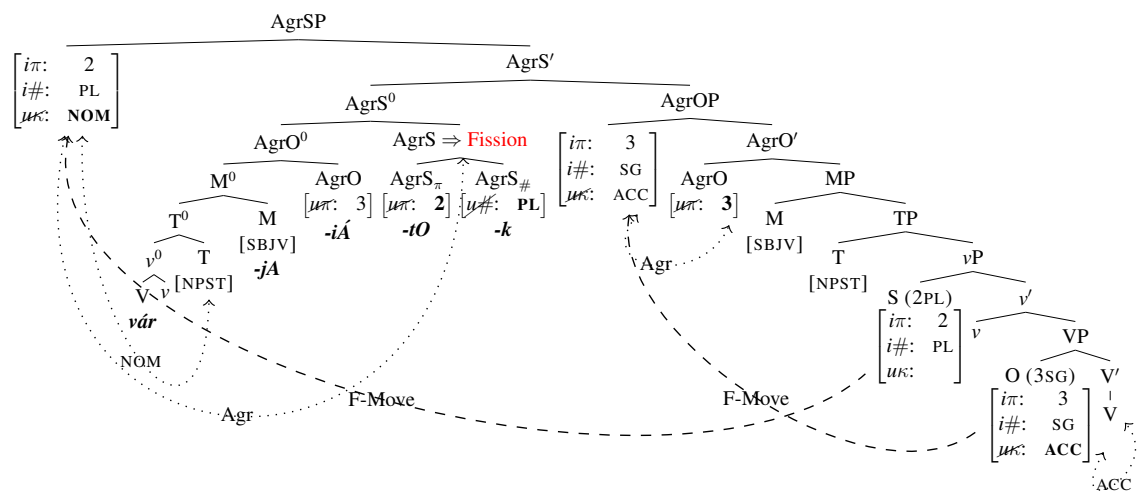

V raises through $v, \mathrm{~T}, \mathrm{M}, \mathrm{AgrO}$, and AgrS. ${ }^{7}$ Agreement and structural case-licensing are autonomous, and occur in spec-head configurations. ${ }^{8}$ The LV vár is spelled out with the closest expressible $\tau$ or $\mu$ c-commanding it (none in non-past indicative, $\tau$ in past indicative, $\mu$ in non-past subjunctive and non-past conditional). All simplex forms easily obey the Mirror Principle. ${ }^{9}$ The hierarchy $\mathrm{V}<\mathrm{T}<\mathrm{M}<$ AgrO $<$ AgrS matches the linear order $\Sigma-\tau / \mu-\pi_{\mathrm{O}}-$ $\pi_{\mathrm{S}}$-\#s ${ }^{10}$ Despite adhering strictly to the Mirror Principle, the Early Minimalist analysis suffers from the semantic vacuity of AgrO and AgrS (Chomsky 1995). LATE MinimALISM (Chomsky 2000) eliminates them and reassociates $\mathrm{O}$ - and $\mathrm{S}$-agreement with $v$ and $\mathrm{T}$, respectively:

Late Minimalism, Simple Agree: derivation of (4), 2PL $\rightarrow 3 \mathrm{SG}$

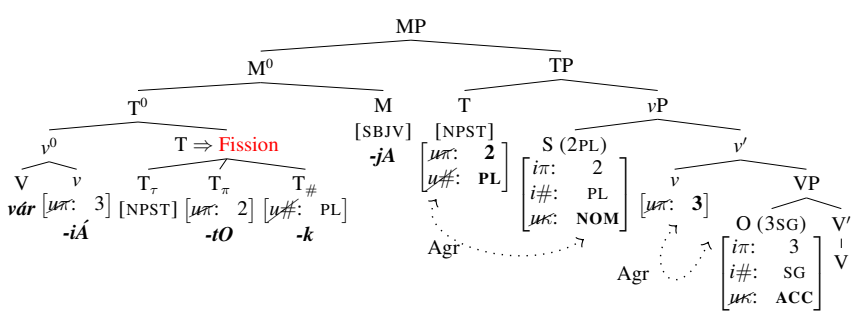

Agree no longer needs a spec-head configuration. A PROBE, say with uninterpretable $\pi[u \pi]$, is valued by interpretable $\pi[i \pi]$ of the closest ACTIVE goal with unvalued case under the probe's c-command. $v$ agrees with $\mathrm{O}$; and $\mathrm{T}$ with $\mathrm{S}$. As a reflex of agreement, $v$ and $\mathrm{T}$ license accusative and nominative case to $\mathrm{O}$ and $\mathrm{S}$, respectively. Agree is SIMPLE: each $\pi$ probe is FLAT, or fully satisfied if the goal has at least the basic $3 \pi$ set $\{\mathrm{REF}\}$ (see $\mathrm{n} 2$ ); and agrees with only

\footnotetext{
${ }^{7}$ In Bartos (2000) and É. Kiss (2002), verbal heads undergo Morphosyntactic Merger rather than cyclic movement. ${ }^{8} \mathrm{O}$ in [Spec,VP] obtains structural accusative case from V. O's features raise to [Spec,AgrOP], to agree with AgrO. $\mathrm{S}$ 's features raise from [Spec, $v \mathrm{P}$ ] to [Spec,AgrSP], receive nominative case from $\mathrm{T}$ (in AgrS ${ }^{0}$ ), and agree with AgrS. ${ }^{9}$ The complex past conditional (6), with expressible $\tau$ and $\mu$, poses a problem. The LV predictably registers $\tau$ but strangely also the agreements, even though $\mathrm{M}$ intervenes hierarchically between AgrS/AgrO and T. For a solution that maintains the Mirror Principle, see É. Kiss (2002:46-47).

${ }^{10}$ I assume that AgrS fissions postsyntactically into separate nodes for person and number.
} 
one goal. (Flat probes should, strictly, be notated as [u3]: Béjar \& Rezac (2009).) But (8) defies the Mirror Principle. Hierarchically, in $\mathrm{V}<v<\mathrm{T}<\mathrm{M}$, all agreement loci are dominated by $\mathrm{M}$, yet linearly, in $\Sigma-\mu-\pi_{\mathrm{O}}-\pi_{\mathrm{S}}-\#_{\mathrm{S}}$, all agreement suffixes follow (not precede) $\mu$.

Under Simple Agree, the person hierarchy $(\mathrm{PH}) 1>2>3$ cannot affect syntax ("which arguments agree with which probe?"), but can affect morphology ("which affixes express agreement?”). Bárány (2018), however, argues for syntactic and morphological PH effects in Hungarian. Before addressing its Cyclic Agree model of syntactic PH effects, I will note its two key morphological assumptions, extrapolated to the non-past subjunctive not examined therein:

(9) Morphological resegmentation of (4) à la Bárány (2018)

\begin{tabular}{|c|c|c|c|}
\hline$(\mathrm{ti}-\varnothing)$ & $($ engem- $\varnothing) /$ & $\begin{array}{l}\text { B vár-j-átok } \\
\text { vár-jA-ÂtOk }\end{array}$ & $(\dddot{0}-\varnothing-\mathrm{t})$ \\
\hline 2PL-NOM & $\begin{array}{l}\text { wait-SBJV-2PL.S } 1 \mathrm{SG}-\mathrm{ACC} \\
\text {, }\end{array}$ & wait-SBJV-3.O:2PL.S & 3-SG-ACC \\
\hline
\end{tabular}

First, in DIRECT contexts ( $\mathrm{S} \geq \mathrm{O}$, e.g., $2 \mathrm{PL} \rightarrow 3 \mathrm{SG}$ ) a portmanteau suffix expresses O- and Sagreement. Second, in INVERSE contexts ( $\mathrm{S}<\mathrm{O}$, e.g., $2 \mathrm{PL} \rightarrow 1 \mathrm{SG})$, only $\mathrm{S}$-agreement is expressed, though $\mathrm{O}$-agreement still occurs, as verified by $\mathrm{O}$ pro-drop (grammatical when singular, marginal to ungrammatical when plural: Keresztes (2014)). While this paper shares neither morphological assumption (for alternatives, see §4), it will highlight the potential of Bárány (2018) to explain some but not all Mirror Principle violations. In Bárány's version of Cyclic Agree (Béjar \& Rezac 2009), Hungarian transitives have two $\pi$ probes $(v, \mathrm{~T})$ in all contexts:

(10) Late Minimalism, Cyclic Agree: derivation of (9)

a. Inverse context $(2 \mathrm{PL} \rightarrow 1 \mathrm{SG})$

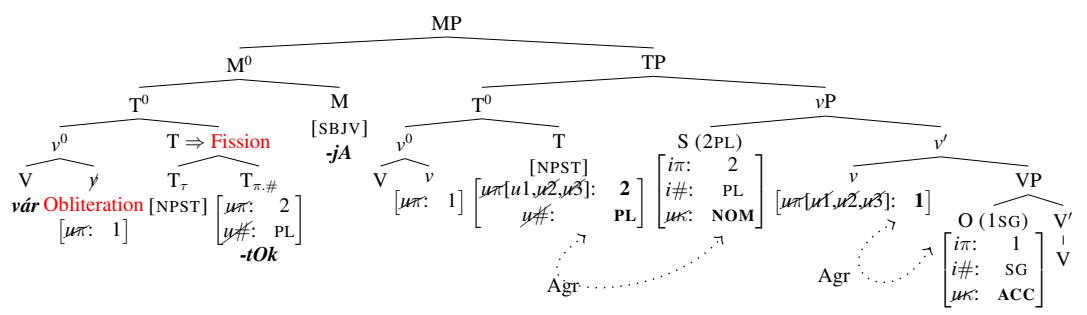

b. Direct context $(2 \mathrm{PL} \rightarrow 3 \mathrm{SG})$

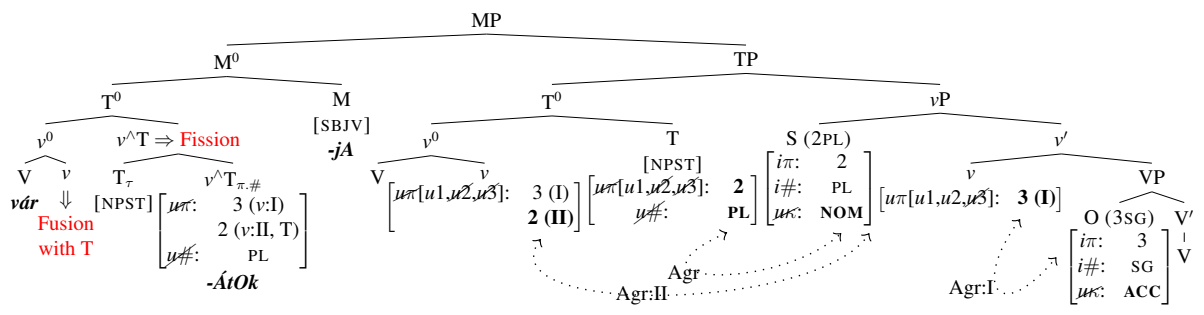

Each $\pi$ probe is ARTICULATED $[u 1, u 2, u 3]$, or fully satisfied only if a goal has $1 \pi\{$ REF, PAR, SPK \}. But it need only be optimally (not fully) satisfied. If it lacks a $1 \pi$ goal in its initial c-command domain, it obtains the $\pi$ set of any available lower-ranked goal. In direct context (10b), $v$ agrees with $3 \pi \mathrm{O}$ in Cycle I. Raised to T, $v$ obtains the $\pi$ set of any goal in the expanded domain which outranks (is a proper superset of) the initial goal's $\pi$ set. $v$ thus agrees with $2 \pi \mathrm{S}$ in Cycle II. T agrees only with $\mathrm{S}$, because $\mathrm{O}$ is no longer active. Neither probe finds a $1 \pi$ goal after exhaustive searching, but the derivation does not crash. Postsyntactically, $v$ and T FUSE into $v^{\wedge} \mathrm{T}$, since their strongest $\pi$ sets (both $2 \pi$ ) match; subsequently, $v^{\wedge} \mathrm{T}$ 
FISSIONS into $\mathrm{T}_{\tau}$ and $v^{\wedge} \mathrm{T}_{\pi \text {.\# }}$ (expressed by a portmanteau for $\pi_{\mathrm{O}}, \pi_{\mathrm{S}}$, and $\#_{\mathrm{S}}$ ). ${ }^{11}$ In inverse context (10a), $v$ agrees with $1 \pi \mathrm{O}$ and is fully satisfied, so after raising to $\mathrm{T}$, it does not agree with S. T agrees only with $\mathrm{S}$. The probes do not fuse, since their strongest $\pi$ sets $(v 1 \pi$; T $2 \pi)$ differ. O-agreement in inverse contexts is unexpressed, either because vocabulary items are absent; or a language-specific rule reserves expression for the highest probe (here T), by postsyntactically OBLITERATING $v$ before vocabulary insertion (Arregi \& Nevins 2012, Bárány 2015).

Under Cyclic Agree, deviations from the Mirror Principle emerge in both direct and inverse contexts. At least for the simplex indicatives (the only forms covered in Bárány (2018)), fusion, fission, and obliteration can ensure the surface linear orders. ${ }^{12}$ But these operations are insufficient for simplex non-indicatives spelling out $\mu$ on the LV. In (10), the original hierarchy in Narrow Syntax is $\mathrm{V}<v<\mathrm{T}<\mathrm{M}$, which becomes $\mathrm{V}<v^{\wedge} \mathrm{T}<\mathrm{M}$ after fusion (direct), and $\mathrm{V}<\mathrm{T}<\mathrm{M}$ after obliteration (inverse), yet the surface linear orders are $\Sigma-\mu-\pi_{\mathrm{O}} . \pi_{\mathrm{S}}$. $\#_{\mathrm{S}}$ (direct) and $\Sigma-\mu-\pi_{\mathrm{S}} \#_{\mathrm{S}}$ (inverse), such that $\mu$ precedes, not follows, the agreement suffixes.

4. New analysis. I will revise the Simple Agree account from (8) by reassigning S-agreement from $\mathrm{T}$ to Pred, under $\mathrm{T}$ and Asp but above $v$, where O-agreement remains. (For the rationale of Pred, see §5.) The surface linear order deviates from the Mirror Principle, because of postsyntactic local dislocation. Obliteration (at least for finite forms) and fusion are unnecessary under my morphological assumptions. First, agreements are expressed always and by separate suffixes for $\mathrm{O}$ and $\mathrm{S}$ (Trommer 2005). Second, $\pi_{\mathrm{O}}$ in inverse contexts is expressed by $-\varnothing$, contrasting with the generally overt suffixes in direct contexts (see Table 6). PH effects emerge not in syntax but only in morphology, through impoverishment rules operating before vocabulary insertion. ${ }^{13}$ (11) shows the revised derivation of (4) just after vocabulary insertion:

Revised Simple Agree: derivation of (4), $2 \mathrm{PL} \rightarrow 3 \mathrm{SG}$

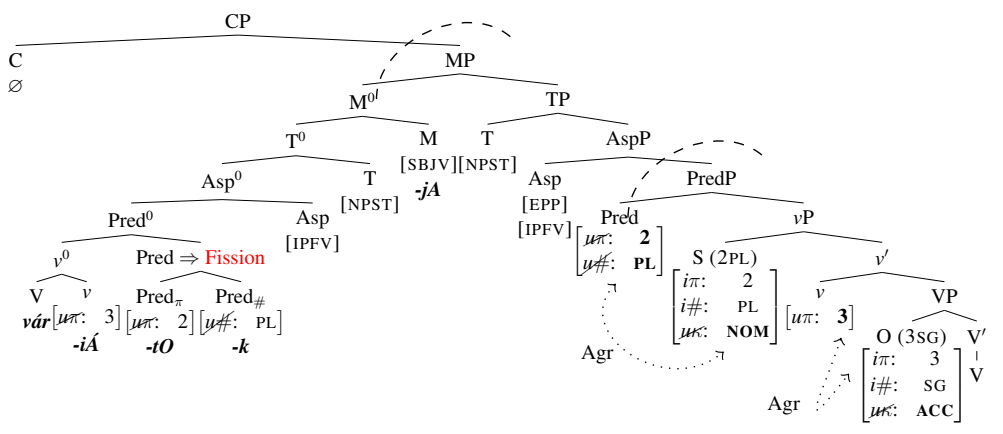

The phases at which the derivation is transferred to Spellout are PredP, MP, and CP (§5).

\footnotetext{
${ }^{11}$ Direct contexts with $3 \pi \mathrm{S}$ and $\mathrm{O}$ are special, since $v$ agrees only with $\mathrm{O}$ and not also with $\mathrm{S}$, but fusion still occurs.

${ }^{12}$ For example, in past indicatives, the original hierarchical order for direct contexts is $\mathrm{V}<v<\mathrm{T}$, becoming $\mathrm{V}<v^{\wedge} \mathrm{T}$ post-fusion, and $\mathrm{V}<\mathrm{T}_{\tau}-v^{\wedge} \mathrm{T}_{\pi}$.\# post-fission, matching the linear order $\Sigma-\tau-\pi_{\mathrm{O}} \cdot \pi_{\mathrm{S}}$. \# $\mathrm{S}$. In inverse contexts, the same original hierarchy becomes $\mathrm{V}<\mathrm{T}_{\tau}-\mathrm{T}_{\pi} \cdot \#$ after obliteration and fission, matching the linear order $\Sigma-\tau-\pi_{\mathrm{S}} \cdot \# \mathrm{~S}$.

13 Trommer's (2005) vocabulary items (VIs) and impoverishment rules (IRs) could be reformulated with the privative subfeatures from $\mathrm{n} 2$ to capture PH effects more explicitly. In inverse contexts, the IRs below would delete $1 \pi$ \{REF, PAR, SPK $\}$ on $v$, given $2 \pi\{$ REF, PAR $\}$ or $3 \pi\{$ REF $\}$ on Pred; and delete $2 \pi$ on $v$, given $3 \pi$ on Pred:

(i) $\quad \mathrm{REF}, \mathrm{PAR}, \mathrm{SPK} \rightarrow \varnothing /[-]_{v_{\pi}}[\mathrm{REF},(\mathrm{PAR})]_{\operatorname{Pred}_{\pi}}[\mathrm{IDV},(\mathrm{GRP})]_{\mathrm{Pred}_{\#}}$

(ii) $\quad$ REF, PAR $\rightarrow \varnothing /[-]_{v_{\pi}}[\mathrm{REF}]_{\operatorname{Pred}_{\pi}}[\mathrm{IDV},(\mathrm{GRP})]_{\operatorname{Pred}_{\#}}$

The IRs bleed insertion on $v$ of overt VIs specified for $1 \pi$, e.g., /-Om/ $\leftrightarrow$ [REF, PAR, SPK $]_{\mathrm{X}_{\pi}}$, and for $2 \pi$, e.g., /-Od/ $\leftrightarrow[\mathrm{REF}, \mathrm{PAR}]_{\mathrm{X}_{\pi}}$, in favor of the null VI specified for $0 \pi,-\varnothing \leftrightarrow[]_{\mathrm{X}_{\pi}}$. Here $\mathrm{X}_{\pi}$ denotes any $\pi$-agreement head, verbal or nominal, since some VIs such as /-OM/ and /-Od/ can serve subject-verb and possessor-noun agreement.
} 
An agreement head's phi-completeness determines when its uninterpretable features are deleted. Pred is PHI-COMPLETE; its $u \pi$ and $u \#$ are deleted immediately after valuation. In contrast, $v$ is PHI-DEFECTIVE, having only $u \pi$, which is deleted when the highest projection reached by $v$ (in this instance MP) is transferred. Delayed deletion enables "long-distance" agreement ( $\$ 7)$.

The hierarchical order in (11), $\mathrm{V}<v<$ Pred $<\mathrm{M}$, does not match the surface linear order $\Sigma-\mu-\pi_{\mathrm{O}}-\pi_{\mathrm{S}^{-}} \#_{\mathrm{S}}$, because items in the complex head $\mathbf{M}^{0}$, after vocabulary insertion and initial linearization, experience LOCAL DISLOCATION (LD) (Embick \& Noyer 2001). ${ }^{14}$

$$
\begin{aligned}
& \text { Initial linearization } \quad \text { KEY. } \underline{\mathrm{X}+\mathrm{Y}} \text { : X adjoins hierarchically to } \mathrm{Y} . \\
& {\left[\mathrm{M}^{0} \mathrm{~V}_{v a ́ r}+v_{-i A}+\left[\operatorname{Pred}_{\pi_{-t O}}+\operatorname{Pred}_{\#-k}\right]+\mathrm{M}_{-j A}\right] \rightarrow\left[\mathrm{M}^{0} \mathrm{~V}_{v a ́ r} * v_{-i A} * \operatorname{Pred}_{\pi_{-t O}} * \operatorname{Pred}_{\#-k} * \mathrm{M}_{-j A}\right]}
\end{aligned}
$$

Local dislocation

INPUT: $\left[\mathrm{M}^{0} \mathrm{~V}_{v a ́ r} * v_{-i A} * \operatorname{Pred}_{\pi_{-t O}} * \operatorname{Pred}_{\#-k} * \mathrm{M}_{-j A}\right]$

1. $\left[\mathrm{M}^{0} \mathrm{~V}_{v a r} * v_{-i A} \oplus \operatorname{Pred}_{\pi_{-t O}} * \operatorname{Pred}_{\#-k} * \mathrm{M}_{-j A}\right]$

2. $\left[\mathrm{M}^{0} \mathrm{~V}_{v a ́ r} * v_{-i A} \oplus \operatorname{Pred}_{\pi_{-t o}} \oplus \operatorname{Pred}_{\#-k} * \mathrm{M}_{-j A}\right]$

3. $\left[\mathrm{M}^{0} \mathrm{~V}_{v a ́ r} * \mathrm{M}_{-j A} \oplus v_{-i A} \oplus \operatorname{Pred}_{\pi_{-t o}} \oplus \operatorname{Pred}_{\# \cdot k}\right]$

$$
\text { OUTPUT: }\left[\mathrm{M}^{0} \mathrm{~V}_{\text {vár }} * \mathrm{M}_{-j A} \oplus v_{-i A} \oplus \operatorname{Pred}_{\pi_{-t o}} \oplus \operatorname{Pred}_{\#-k}\right]
$$

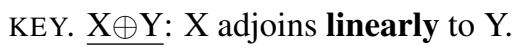

In hierarchical structure (11) after vocabulary insertion, $\mathbf{M}^{0}$ is a MORPHOSYNTACTIC WORD (MWd), a head undominated by another head, comprising five SUBWORDS (SWd), or nonMWd terminal heads: $\mathrm{V}_{v a ́ r}, v_{-i \hat{A}}, \operatorname{Pred}_{\pi_{-t} O}, \operatorname{Pred}_{\#-k}, \mathrm{M}_{-j A}$. After initial linearization (12), dehierarchicized SWds can undergo LD (13), by which a SWd trades an immediate LINEAR ADJACENCY relation $(*)$ to another SWd for a LINEAR ADJUNCTION relation $(\oplus)$ to a peripheral element of the other. This adjunction operates on a flat string, unlike earlier HIERARCHICAL ADJUnCtion (+). To reorder $\mathrm{M}_{-j A}$ between $\mathrm{V}_{v a ́ r}$ and $v_{-i A}$, LD must be iterated. The first two cycles are string-vacuous (non-inverting) and feed the only inverting cycle. In Cycle 1, $v_{-i A}$ left-adjoins to $\operatorname{Pred}_{\pi_{-t o}}$, forming a complex SWd $v_{-i A} \oplus \operatorname{Pred}_{\pi_{-t o}}$; which in Cycle 2 left-adjoins to Pred $\#_{-k}$, creating $v_{-i A} \oplus \operatorname{Pred}_{\pi_{-t o}} \oplus \operatorname{Pred}_{\#-k}$; with which $\mathrm{M}_{-j A}$ inverts in Cycle 3, making all agreement suffixes follow $\mathrm{M}_{-j A} \cdot{ }^{15}$ Diachronically, the lexical specification to follow $\tau / \mu$ verbfinally might be traced to the origin of some agreement suffixes, e.g., /-iÁ/, as Proto-Uralic enclitic pronouns (cf. den Dikken 2018), and was extended even to suffixes of non-clitic origin.

The new analysis can also accommodate the complex past conditional:

Complex verbal head in (6), $2 \mathrm{PL} \rightarrow 3 \mathrm{SG}$

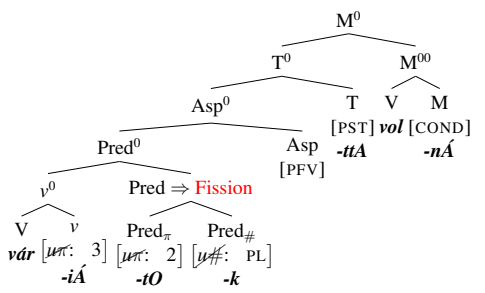

The LV vár is spelled out with $\tau$ since it is a closer expressible feature than $\mu$. To support the $\mu$ suffix, the DV vol adjoins to $\mathrm{M}$ at vocabulary insertion. The whole past conditional amounts to one MWd, $\mathrm{M}^{0}$. The first five $\mathrm{SWds}\left(\mathrm{V}_{v a ́ r}, v_{-i A}, \operatorname{Pred}_{\pi_{-t o}}, \operatorname{Pred}_{\#-k}, \mathrm{~T}_{-t t A}\right)$ belong to the inflected $\mathrm{LV}$, and the last two SWds $\left(\mathrm{V}_{v o l}, \mathrm{M}_{-n A}\right)$ belong to the inflected DV. As in (13), LD manipulates

\footnotetext{
${ }^{14}$ Whether vocabulary insertion immediately precedes linearization (Bobaljik 2000), as assumed in (11), or vice versa (Embick 2015, Arregi \& Nevins 2012), LD can only follow both processes.

${ }^{15}$ Under Cyclic Agree (10), LD would apply after fusion/obliteration/fission, vocabulary insertion, and linearization.
} 
the initial linearization of the SWds from the inflected $\mathrm{LV}$, but with $\mathrm{T}_{-t t A}$ instead of $\mathrm{M}_{-j A}$ :

$$
\begin{aligned}
& \text { Local dislocation } \\
& \text { INPUT: }\left[\mathrm{M}^{0} \mathrm{~V}_{v a ́ r} * v_{-i A} * \operatorname{Pred}_{\pi_{-t o}} * \operatorname{Pred}_{\#-k} * \mathrm{~T}_{-t t A} * \mathrm{~V}_{v o l} * \mathrm{M}_{-n A}\right] \\
& \text { 1. }\left[\mathrm{M}^{0} \mathrm{~V}_{v a r r} * v_{-i A} \oplus \operatorname{Pred}_{\pi_{-t o}} * \operatorname{Pred}_{\#-k} * \mathrm{~T}_{-t t A} * \mathrm{~V}_{v o l} * \mathrm{M}_{-n A}\right] \\
& \text { 2. }\left[\mathrm{M}^{0} \mathrm{~V}_{v a ́ r} * v_{-i A} \oplus \operatorname{Pred}_{\pi_{-t o}} \oplus \operatorname{Pred}_{\#-k} * \mathrm{~T}_{-t t A} * \mathrm{~V}_{v o l} * \mathrm{M}_{-n A ́}\right] \\
& \text { 3. }\left[\mathrm{M}^{0} \mathrm{~V}_{v a ́ r} * \mathrm{~T}_{-t t A} \oplus v_{-i A} \oplus \operatorname{Pred}_{\pi_{-t o}} \oplus \operatorname{Pred}_{\#-k} * \mathrm{~V}_{v o l} * \mathrm{M}_{-n A}\right] \\
& \text { OUTPUT: }\left[\mathrm{M}^{0} \mathrm{~V}_{v a ́ r} * \mathrm{~T}_{-t t A} \oplus v_{-i A} \oplus \operatorname{Pred}_{\pi_{-t o}} \oplus \operatorname{Pred}_{\#-k} * \mathrm{~V}_{v o l} * \mathrm{M}_{-n A}\right]
\end{aligned}
$$

The MWd-SWd distinction explains the behavior of clitics with the past conditional. Clitics such as interrogative $=e$ select MWds as hosts, e.g., vártam volna, not SWds, e.g., -tam:

$$
\begin{aligned}
& \text { a. Mari- } \varnothing \text { nem tud-t-a- } \varnothing-\varnothing \text {, } \\
& \text { tud-ttA-iÁ- } \varnothing-\varnothing \text {, } \\
& \text { hogy vár-ta-m- } \varnothing \quad \text { vol-na }=\mathbf{e} \\
& \text { vár-ttA-Om- } \varnothing \quad \text { vol-nÁ=e } \\
& \text { Mary-NOM not know-PST-3.O-3.S-SG.S that wait-PST-1.S-SG.S be-COND=Q } \\
& \begin{array}{lll}
\text { b. } * \text { Mari- } \varnothing \quad \text { nem tud-t-a- } \varnothing-\varnothing, & \text { hogy vár-ta-m- } \varnothing=\mathbf{e} & \begin{array}{l}
\text { vol-na } \\
\text { vár-ttA-Om- } \varnothing=\mathbf{e}
\end{array} \\
\text { vol-nÁ }
\end{array} \\
& \text { Mary-NOM not know-PST-3.O-3.S-SG.S that wait-PST-1.S-SG.S=Q be-COND } \\
& \text { 'Mary didn't know whether I would have waited.' (Dalmi 2005:102, reglossed) }
\end{aligned}
$$

5. PredP. Before discussing Pred as a S-agreement locus, I will note the independent motivations for the silent heads Pred and Asp. Pred licenses predicates, including V (primary predicate), and any COVERB (CV) particle merged in [V,Comp] (secondary predicate, often telicizing). Each bears a [PRED] feature to be checked in PredP: V+v raises to Pred; CV raises to [Spec,PredP] (É. Kiss 2008c). Bare NP objects from [Spec,VP] also possess and check [PRED] like CVs. Asp hosts aspect $\alpha$ (imperfective, perfective) and EPP features, regulating CV's final position (Csirmaz 2008). ${ }^{16}$ My analysis below of Pred as S-agreement locus could also apply to Asp, if Asp existed alone (É. Kiss 2002) and assumed Pred's functions and phasehood.

The standard Minimalist phases are CP and $v$ P, but I will adopt É. Kiss's (2008a) proposal that in Hungarian, PredP (not $v \mathrm{P}$ ) is the lowest, LEXICAL phase in which all the verb's complements (arguments and predicates) are licensed. The next, FUNCTIONAL phase corresponds to the highest projection reached by $\mathrm{V}$ : MP in neutral clauses, $\mathrm{NNeP}$ in non-neutral ones. ${ }^{17} \mathrm{CP}$ remains the final phase. I now analyze phasal constraints on possible S-agreement loci in (17).

(17) a. Pred-probe

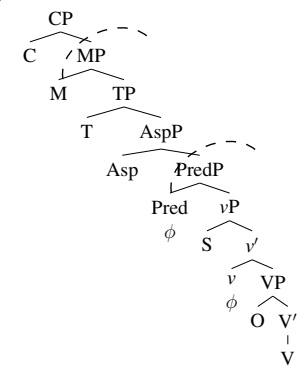

b. T-probe

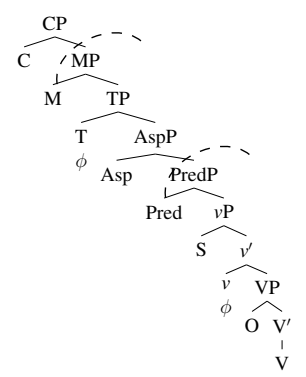

${ }^{16} \mathrm{CV}$-licensing in [Spec,PredP] is illustrated for $\mathrm{fel}$ 'up' in (40a). Asp's EPP can be satisfied by raising CV to [Spec,AspP]. As V+v+Pred+Asp raises to T and M, CV moves through the respective specifiers to [Spec,MP], where it stops, even if the verb raises higher in non-neutral clauses. If CV does not exist or must remain in [Spec,PredP] because it is telicizing and $\alpha$ is IPFV, EPP is satisfied instead by raising V+v+Pred to Asp (which happens anyway). ${ }^{17} \mathrm{NNeP}$ (non-neutral phrase) dominates MP and projects NegP and/or FocP (É. Kiss 2008c), e.g., in (41b). After the domain of each Hungarian phase head (Pred, M, NNe) is transferred to PF, the domain's hierarchical structure is flattened, and its constituents are linearizable in any order. Accordingly, word order is preverbally fixed and postverbally free (É. Kiss 2008a). 
(18) Strong Phase Impenetrability Condition (Chomsky 2000, Richards 2012:136)

In phase HP with head $\mathrm{H}$, the domain of $\mathrm{H}$ is not accessible to operations outside HP. Only $\mathrm{H}$ and its edge [specifier(s)] are accessible.

(19) Weak Phase Impenetrability Condition (Chomsky 2001, Richards 2012:137)

[Given structure [zP Z ... [HP $\delta$ [H YP]]], with $\mathrm{H}$ and $\mathrm{Z}$ the heads of phases]: The domain of $\mathrm{H}$ is not accessible to operations at ZP. Only $\mathrm{H}$ and its edge are accessible.

The accessibility of $S$ to a probe can depend on the version of the Phase Impenentrability Condition. Regardless of Strong or Weak PIC, a Pred-probe (17a) can access S in [Spec, $v$ P], since both belong to the PredP phase. But a T-probe (17b) cannot access S under Strong PIC, since Pred transfers its domain $v \mathrm{P}$ as soon as the next head Asp is merged. But under Weak PIC, T can access S, since $v \mathrm{P}$ is transferred only when $\mathrm{M}$, the next phase head after Pred, is merged. While plausible, the last scenario (T-probe, Weak PIC) might be less likely, given the free/fixed word order phenomena in É. Kiss (2008a) apparently requiring Strong PIC, as well as historical considerations. In Old Hungarian, the S-agreement locus was no higher than Asp.

6. Old Hungarian. Unlike in Modern Hungarian $(\mathrm{MH})$, verbs in Old Hungarian $(\mathrm{OH})$ could morphologically inflect for aspect $\alpha$, as well as tense $\tau$ and mood $\mu .^{18}$

(20) Simple non-past indicative

mond- $\varnothing$-om- $\varnothing$

mond- $\varnothing-\mathrm{Om}-\varnothing$

say-3.0-1.S-SG.S

'I \{say, am saying $\}$ it.'

(21) Simple past indicative

mond-á- $\varnothing-\mathrm{m}-\varnothing$

mond-Á- $\varnothing-\mathrm{Om}-\varnothing$

say-PST-3.O-1.S-SG.S

'I said it.'

(22) Perfective non-past indicative

mond-ta- $\varnothing$-m- $\varnothing$

mond-ttA- $\varnothing-\mathrm{Om}-\varnothing$

say-PFV-3.O-1.S-SG.S

'I have said it.'

(23) Imperfective past indicative

mond- $\varnothing-\varnothing$-om- $\varnothing \quad$ val-a

mond- $\varnothing-\varnothing-$-Om- $\varnothing \quad$ val-Á

say-IPFV-3.O-1.S-SG.S be-PST

'I was saying it.'

(24)

The MH equivalents are also presented for comparison:

(28) Non-past indicative

mond- $\varnothing$-om- $\varnothing$

mond- $\varnothing-\mathrm{Om}-\varnothing$

say-3.0-1.S-SG.S

'I \{ say, am saying\} it.'
(29)

Past indicative

mond-ta- $\varnothing-\mathrm{m}-\varnothing$

mond-ttA- $\varnothing-\mathrm{Om}-\varnothing$

say-PST-3.0-1.S-SG.S

'I \{ said, was saying, have said, had said \} it.'
Perfective past indicative

mond-ta- $\varnothing-\mathrm{m}-\varnothing \quad$ val-a

mond-ttA- $\varnothing-\mathrm{Om}-\varnothing \quad$ val-Á

say-PFV-3.O-1.S-SG.S be-PST

'I had said it.'

Non-past subjunctive

mond-ja- $\varnothing-\mathrm{m}-\varnothing$

mond-jA- $\varnothing-\mathrm{Om}-\varnothing$

say-SB JV-3.O-1.S-SG.S

'[that] I should say it.'

Simple non-past conditional

mond-aná- $\varnothing-\mathrm{m}-\varnothing$

mond-nÁ- $\varnothing-\mathrm{Om}-\varnothing$

say-COND-3.O-1.S-SG.S

'I would say it.'

Perfective non-past conditional

mond-ta- $\varnothing$-m- $\varnothing \quad$ vol-na

mond-ttA- $\varnothing-\mathrm{Om}-\varnothing \quad$ vol-nÁ

say-PFV-3.O-1.S-SG.S be-COND

'I would have said it.'

${ }^{18}$ Data are reglossed from É. Kiss (2017) and Hungarian Generative Diachronic Syntax corpus (oldhungariancorpus. nytud.hu). 
(31) Non-past conditional

mond-aná- $\varnothing-\mathrm{m}-\varnothing$

mond-nÁ- $\varnothing-\mathrm{Om}-\varnothing$

Say-COND-3.O-1.S-SG.S

'I would say it.'
(32)

$\begin{array}{ll}\text { Past conditional } & \\ \text { mond-ta- } \varnothing-\mathrm{m}-\varnothing & \text { vol-na } \\ \text { mond-ttA- } \varnothing-\mathrm{Om}-\varnothing & \text { vol-nÁ } \\ \text { say-PST-3.O-1.S-SG.S } & \text { be-COND } \\ \text { 'I would have said it.' } & \end{array}$

I assume that $\mathrm{OH}$ shares the same inventory of verbal projections and phases (and Strong PIC) as $\mathrm{MH}$. In $\mathrm{OH}$, the LV mond registers $\alpha$ (to the exclusion of $\tau$ and $\mu$, since Asp is closer than T/M to V), if $\alpha$ 's value is expressible, namely imperfective (23) or perfective $(22,24,27)$. Unspecified $\alpha$ is inexpressible $(20,21,25,26)$. When the LV registers $\alpha$, past $\tau(23,24)$ and conditional $\mu$ (27) appear on the DV val/vol. T cannot be the locus of S-agreement, since the $\alpha$ marked LV agrees but the $\tau$-marked DV val-a does not $(23,24)$. S-agreement thus occurs no higher than Asp. For consistency with $\mathrm{MH}$, I locate S-agreement in $\mathrm{OH}$ also on Pred:

Complex verbal head in $\mathrm{OH}$ perfective non-past conditional (27) (cf. MH (14)) ${ }^{19}$

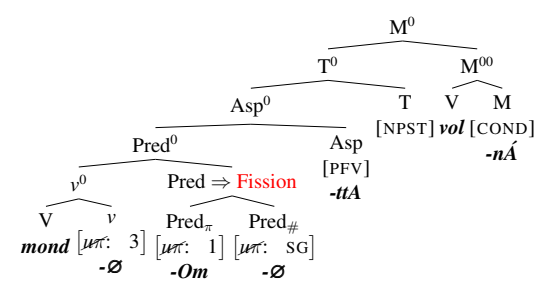

Pred was undisturbed by the following changes from $\mathrm{OH}$ to $\mathrm{MH}$. Syntactically, $\mathrm{OH}$ Asp was reanalyzed as $\mathrm{MH} \mathrm{T,} \mathrm{while} \mathrm{morphologically,} \mathrm{OH} \mathrm{PFV} \alpha$ suffix /-ttA/ $(22,27)$ was reinterpreted as MH PST $\tau$ /-ttA/ $(29,32)$, and OH IPFV $\alpha$ suffix $-\varnothing$ (23) was lost. Both OH T and PST $\tau$ suffix /-Á/ (21) vanished. MH developed a new, morphologically unexpressed Asp to host $\alpha .^{20}$

7. Infinitives. I now extend the revised Simple Agree account to infinitives embedded under the classes of matrix verbs represented by kell 'must' and akar 'want'. The Hungarian infinitival clause begins as a CP (with possible left-peripheral projections, e.g., TopP, FocP), in a biclausal structure with the matrix CP, even if restructuring can later occur (Szécsényi 2009).

(34) Epistemic kell

a fiú-k-nak $k_{j}$ már otthon kell- $\varnothing-\varnothing \quad\left[\mathrm{C}_{\mathrm{I} . \mathrm{N}}\right.$ len-ni(j)-ü-k/ ${ }^{*}$ len-ni- $\left.\varnothing-\varnothing / \quad \boldsymbol{e}_{j}\right]$ the boy-PL-DAT already home must-0.S-NN.S be-INF-3.S-PL.S/ *be-INF-0.S-NN.S/ 'The boys must already be at home.'

(35) Deontic kell

a. Matrix experiencer, controlling pro infinitival $\mathrm{S}$

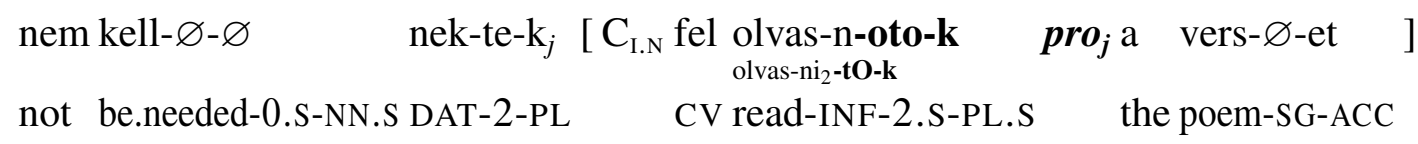

b. Matrix experiencer, controlling $P R O$ infinitival $\mathrm{S}$ nem kell- $\varnothing-\varnothing$
nek-te-k $\mathrm{k}_{j}\left[\mathrm{C}_{\mathrm{I} . \mathrm{N}}\right.$ fel olvas-ni- $\varnothing-\varnothing$
$\boldsymbol{P R O}_{j}$ a vers- $\varnothing$-et
olvas-ni $-\varnothing-\varnothing$
not be.needed-0.S-NN.S DAT-2-PL
CV read-INF-O.S-NN.S
the poem-SG-ACC

\footnotetext{
${ }^{19}$ The surface linear order in (27) is derived by LD as in MH past conditional (15), but substituting Asp-ttA for $\mathrm{T}_{-t t A}$.

${ }^{20}$ In an alternative account (É. Kiss 2008b:148), no new Asp emerged in MH, since Pred now performs the functions of OH Pred and Asp. In another account (É. Kiss 2017:72), OH Pred was reanalyzed as MH Asp, so MH lacks Pred.
} 
c. No matrix experiencer; uncontrolled pro infinitival $\mathrm{S}$

nem kell- $\varnothing-\varnothing$

[ $\mathrm{C}_{\mathrm{I} . \mathrm{N}}$ fel olvas-n-oto-k olvas-ni 2 -to-k $_{j}$ a vers- $\varnothing$-et ]

not be.needed-0.S-NN.S

CV read-INF-2.S-PL.S the poem-SG-ACC

Same translation: 'It is not necessary for you(pl) to read out the poem.'

(36) akar

a. $3 \mathrm{SG}$ (definite DP) infintival O

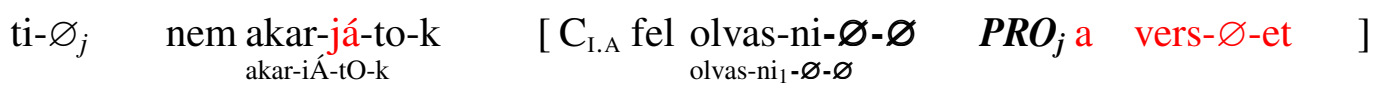

2PL-NOM not want-3.O-2.S-PL.S CV read-INF-0.S-NN.S the poem-SG-ACC

'You(pl) don't want to read out the poem.'

b. $\quad$ SS (indefinite NumP) infintival $\mathrm{O}$

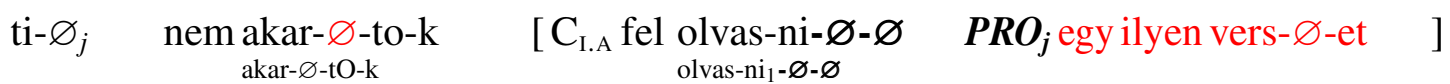

2PL-NOM not want-0.O-2.S-PL.S CV read-INF-0.S-NN.S a such poem-SG-ACC

'You(pl) don't want to read out such a poem.'

Infinitives agree in $\pi$ and \# with their overt S (34) and pro S (35a,35c), but not PRO S $(35 b, 36)$, where the null suffixes express default values ( 0 for $\pi$ and $N N$ for \#) without actual valuation by $P R O$. The overt S 'the boys' (34) bears dative case (instead of nominative for finite S). Although 'the boys' appears in the matrix CP, it originates from the infinitival CP (É. Kiss 2002), since epistemic kell cannot assign a theta-role to it. In contrast, deontic kell (35) can take a dative experiencer nektek controlling an in situ pro (35a) or PRO (35b) infinitival S. It can also omit the experiencer entirely (35c), leaving pro uncontrolled. I assume that the pro $\mathrm{S}$ has the same dative case as 'the boys' in (34), while $P R O$ is caseless.

$$
\begin{aligned}
& \text { lejár-t- } \varnothing-\varnothing \quad \text { a jogosítvány- } \varnothing-\varnothing-\varnothing-\text { jom- } \varnothing-\varnothing \\
& \text { lejár-ttA- } \varnothing-\varnothing
\end{aligned}
$$

expire-PST-3.S-SG.S the license-PSM-SG.PSM-1.PSR-SG.PSR-NOM

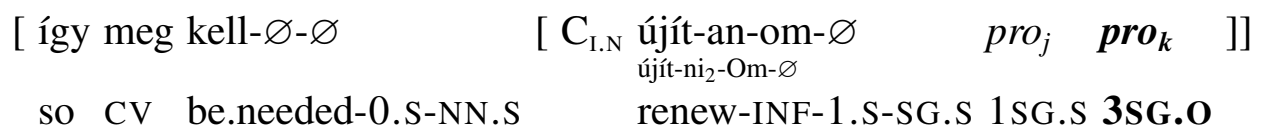

'My license expired, so I need to renew it.' (Ruda 2017:78, reglossed)

Although O-agreement is morphologically unexpressed on infinitives, it syntactically does occur, for two reasons. First, infinitival O is pro-droppable (37). Second, O-infinitive agreement is an integral step of local Agree for "long-distance" object agreement (LOA) in which matrix akar, but not kell, registers the infinitival O's $\pi(3 \pi(36 \mathrm{a}) ; 0 \pi(36 \mathrm{~b})) .{ }^{21}$ LOA's availability depends on the flavor of $\mathrm{C}_{\mathrm{I}}$ (complementizer of infinitival CP), namely $\mathrm{C}_{\mathrm{I} . \mathrm{N}}$ under kell and $\mathrm{C}_{\mathrm{I} . \mathrm{A}}$ under $a k a r$, which both begin with unvalued structural case. $\mathrm{C}_{\mathrm{I} . \mathrm{N}}$ is later valued nominative, and $\mathrm{C}_{\mathrm{I} . \mathrm{A}}$, accusative. Only $\mathrm{C}_{\mathrm{I} . \mathrm{A}}$ also has an unvalued interpretable $\pi$ probe, unlike the canonical uninterpretable $\pi$ probes on $v$ and T (Pesetsky \& Torrego 2007), to allow LOA by transmitting the $\pi$ from infinitival $v$ (ultimately from O) to matrix $v$ (cf. Szécsényi \& Szécsényi 2017). $C_{I}$ 's case values are confirmed by the fact that when kell and akar select finite CPs, they agree with a $3 \mathrm{SG}$ cataphor $a z$ referring to the $\mathrm{CP}$ and bearing the same case values:

${ }^{21}$ Roughly generalizing, definites are DPs with non-empty $\pi$ and indefinites are non-DPs with no $\pi$ (Bárány 2018). 
nem kell- $\varnothing-\varnothing$

(nek-te-k) az- $\varnothing$

[ hogy fel olvas-s-a- $\varnothing-\varnothing$

a vers- $\varnothing$-et ]

not be.needed-3.S-SG.S DAT-2-PL DEM-NOM that CV read-SBJV-3.0-3.S-SG.S the poem-SG-ACC 'It is not necessary (for you(pl)) that she read out the poem.'
ti- $\varnothing$
nem akar-já-to-k
az-t
[ hogy fel olvas-s-a- $\varnothing-\varnothing$
a vers- $\varnothing$-et akar-iÁ-tO-k
olvas-jA-iÁ- $\varnothing-\varnothing$

2PL-NOM not want-3.O-2.S-PL.S DEM-ACC that CV read-SBJV-3.0-3.S-SG.S the poem-SG-ACC

'You(pl) don't want her to read out the poem.'

I now consider the derivation of (35a), with $\mathrm{C}_{\mathrm{I} . \mathrm{N}}$ under kell.

Derivation of (35a)

a. Embedded clause

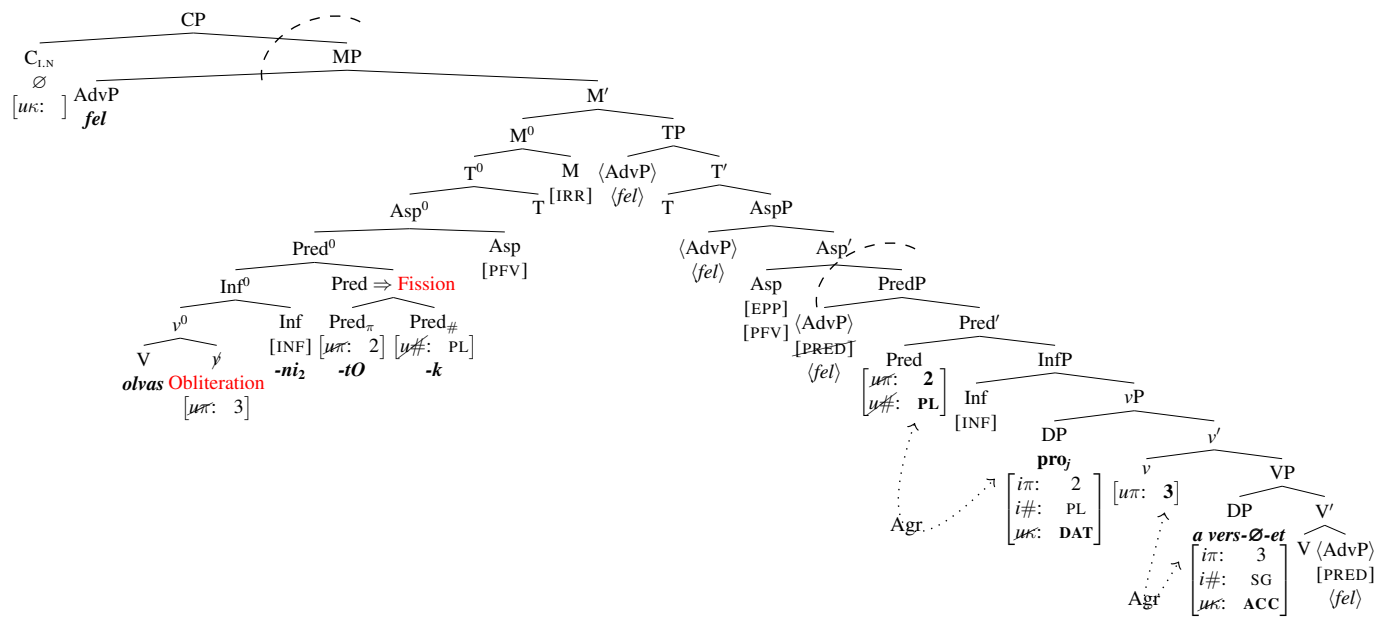

b. Matrix clause

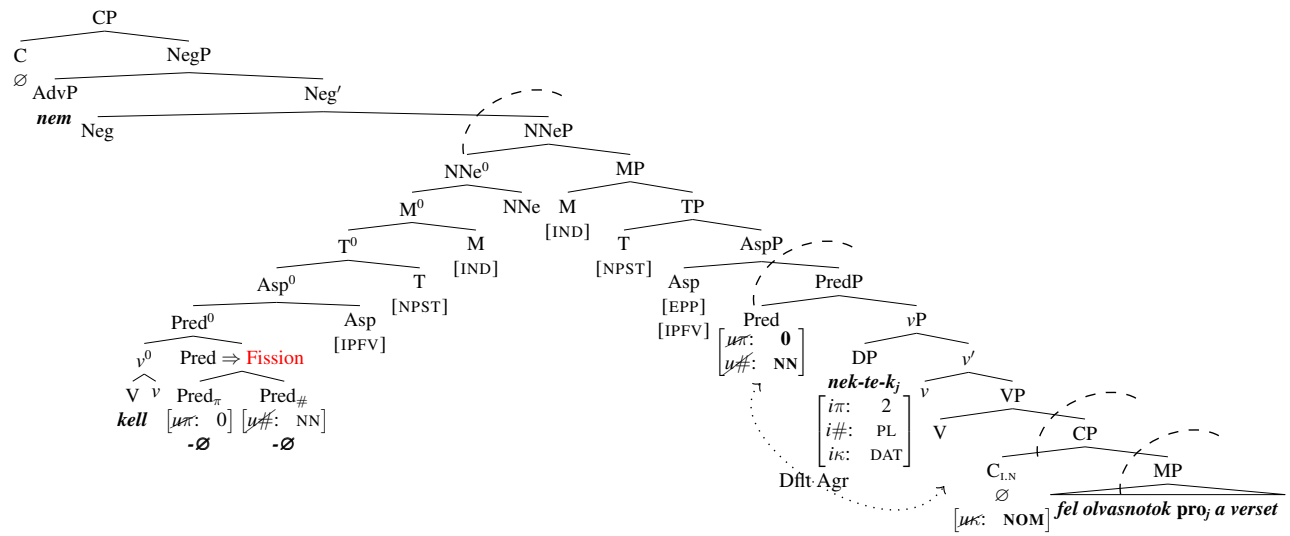

In infinitival CP (40a), the verb projects Inf (between $v$ and Pred), $\mathrm{T}$ with unspecified $\tau$, and $\mathrm{M}$ with irrealis $\mu$. $\mathrm{O}$ agrees with $v$ for accusative case, and $\mathrm{S}$ with Pred for dative. The INF feature resides not on T but Inf, just above $v$ (cf. Travis 2000), to give Pred the infinitival flavor for licensing structural dative case instead of nominative. The $u \pi$ on $v$ is not instantly deleted after valuation, because $v$ is phi-defective (without \#), unlike phi-complete Pred (with $\pi$ and \#) (cf. Richards 2012:146n6). $v$ becomes a potential goal for further Agree. The highest head that $v$ reaches in a neutral infinitive is $\mathrm{M}$. But even from there, $v$ can never agree with $\mathrm{C}_{\mathrm{I} . \mathrm{N}}$, which lacks a $\pi$ probe. The $u \pi$ on $v$ is deleted just before MP, the domain of phase head $\mathrm{C}_{\mathrm{I} . \mathrm{N}}$, is transferred (when matrix $\mathrm{V}$, the head after $\mathrm{C}_{\mathrm{I} . \mathrm{N}}$, is merged, assuming Strong PIC). $v$ 
is obliterated postsyntactically in the context of INF, precluding expression of $\pi_{\mathrm{O}}$ on the infinitive, so $\pi_{\mathrm{O}^{-}}$and INF-suffixes exhibit complementary distribution. The hierarchical order of morphemes, $\mathrm{V}<\mathrm{Inf}<$ Pred, matches the surface linear order $\Sigma-\mathrm{INF}-\pi_{\mathrm{S}^{-}} \#_{\mathrm{S}}$, without LD.

In matrix CP (40b), the probes on Pred, a CASE-LICENSING HEAD, seek a goal with unvalued structural case (and valued $\pi$ and \#). The experiencer nektek in [Spec, $v \mathrm{P}]$ already has inherent dative case, while $\mathrm{C}_{\mathrm{I} . \mathrm{N}}$ has unvalued structural case but no $\pi$ and \#. Under this exigency, Pred and $\mathrm{C}_{\mathrm{I} . \mathrm{N}}$ resort to default Agree. Pred licenses nominative case to $\mathrm{C}_{\mathrm{I} . \mathrm{N}}$, but default $\pi$ and \# values are inserted on Pred without actual valuation by $\mathrm{C}_{\mathrm{I} . \mathrm{N}}$. The infinitival $\mathrm{CP}$, not the experiencer, is thus the true $\mathrm{S}$ of kell. (As an intransitive, kell has no v-probe.)

The derivation of (36a), with $\mathrm{C}_{\mathrm{I} . \mathrm{A}}$ under akar, is provided below:

Derivation of (36a)

a. Embedded clause

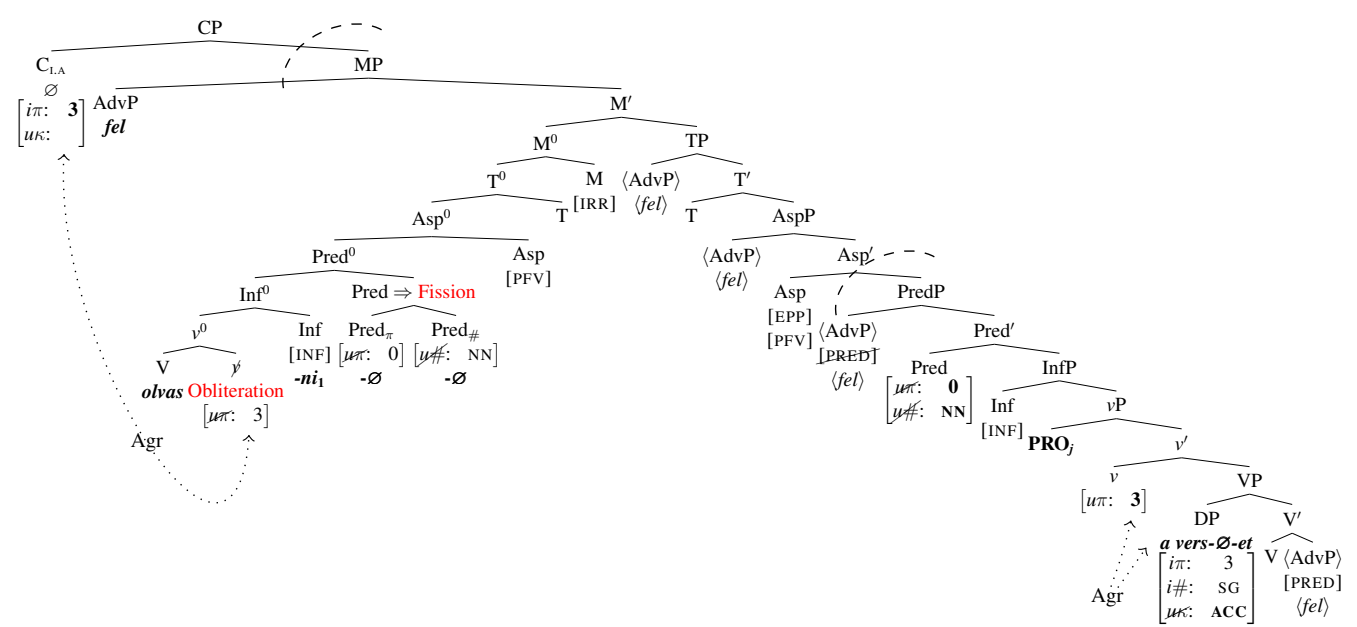

b. Matrix clause

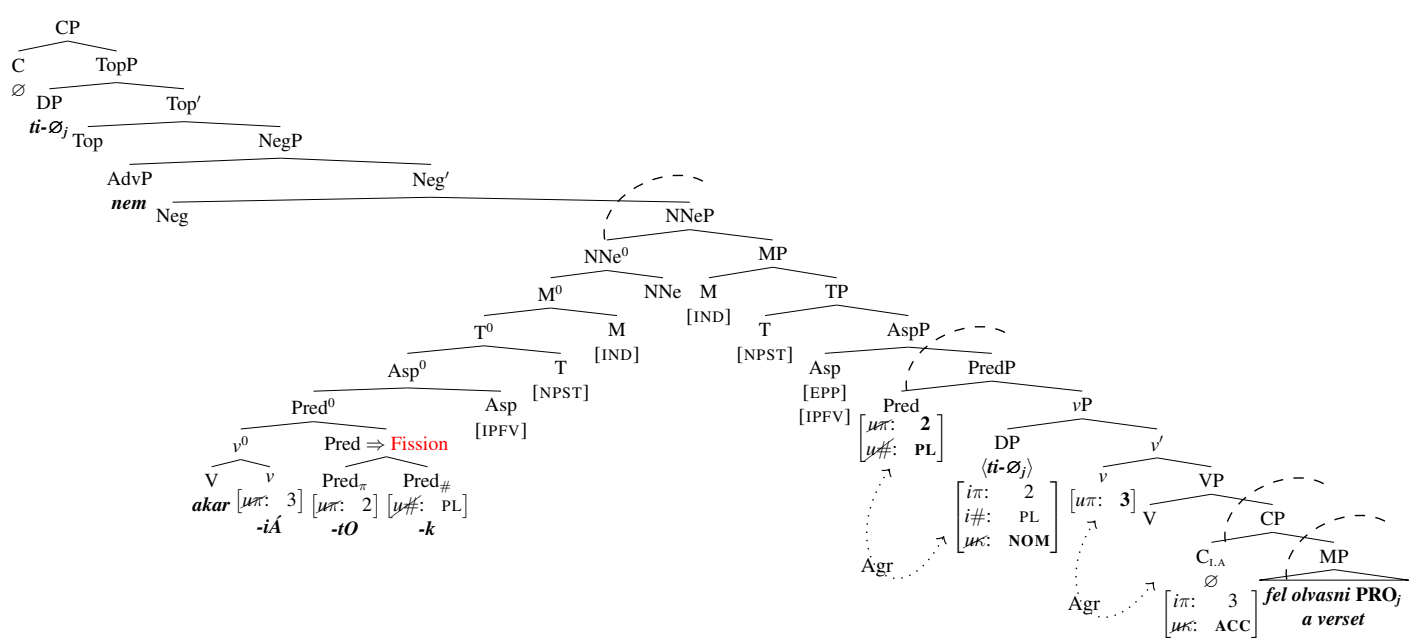

In infinitival CP (41a), $\mathrm{O}$ agrees with $v$, but Pred agrees with nothing, since caseless $P R O$ and $v$ are ineligible goals for probes on case-licensing heads. Agree is a fallible operation, so the derivation continues unproblematically (Preminger 2014); Pred's $\pi$ and \# are valued by default, and dative case is unlicensed. Since $\pi$ on $v$, raised to $\mathbf{M}$, is not deleted until the transfer of MP (when matrix $\mathrm{V}$ merges), $v$ can agree as a goal with $\mathrm{C}_{\text {I.A }}$ 's $\pi$ probe. ${ }^{22}$ The interpretable

\footnotetext{
${ }^{22}$ Unlike Pred and $v, \mathrm{C}_{\text {I.A }}$ is not a case-licensing head, so its probe seeks a caseless goal, such as infinitival $v$.
} 
$\pi$ on $\mathrm{C}_{\mathrm{I} . \mathrm{A}}$ is never deleted. With its yet unvalued structural case, $\mathrm{C}_{\mathrm{I} . \mathrm{A}}$ in (41b) agrees as a goal with matrix $v$ for accusative case, so infinitival O's $\pi$ finally arrives at a morphologically expressible head. In sum, LOA enchains three instances of local Agree: infinitival O-infinitival $v$; infinitival $v-\mathrm{C}_{\text {I.A }} ; \mathrm{C}_{\text {I.A }}-$ matrix $v$. The Pred of akar agrees with and licenses nominative case to the experiencer $t i$ in [Spec, $v \mathrm{P}]$, unlike the non-agreeing, inherent dative experiencer of kell.

8. Conclusion. Under any Minimalist analysis of Hungarian that reassigns agreement from AgrSP/AgrOP to semantically contentful heads, whether with Simple or Cyclic Agree, the surface linear order of affixes deviates in some instances from the hierarchical order of heads. Postsyntactic local dislocation of the initial linearization derives the deviations. The revised Simple Agree account presented here maintains O-agreement canonically on $v$, but identifies Sagreement with Pred (or possibly Asp) rather than T. From Pred, the probes thereon can access $\mathrm{S}$ in $[\mathrm{Spec}, v \mathrm{P}]$, under the assumptions that PredP is a phase, and that the Strong PIC applies. (The account also extends to Old Hungarian, in which S-agreement occurred no higher than Asp.) Whereas finite Pred licenses structural nominative case to $S$, infinitival Pred licenses dative. To impart an infinitival flavor to Pred, the INF feature resides on Inf (below Pred), rather than $\mathrm{T}$ (above). In both finite and infinitival clauses, feature deletion after valuation is instant on Pred (phi-complete), but delayed on $v$ (phi-defective) until the transfer of the highest projection reached by $v$. The delay enables features on infinitival $v$ (from infinitival $\mathrm{O}$ ) to pass to infinitival C and matrix $v$, producing "long-distance" O-agreement.

\section{References}

Abondolo, Daniel. 1988. Hungarian inflectional morphology. Budapest: Akadémiai Kiadó.

Arregi, Karlos \& Andrew Nevins. 2012. Morphotactics: Basque auxiliaries and the structure of spellout. Dordrecht: Springer.

Baker, Mark. 1985. The mirror principle and morphosyntactic explanation. Linguistic Inquiry 16(3). 373-415.

Bárány, András. 2015. Inverse agreement and Hungarian verb paradigms. In Katalin É. Kiss, Balázs Surányi \& Éva Dékány (eds.), Approaches to Hungarian 14, 37-64. Amsterdam: John Benjamins.

Bárány, András. 2018. Person, case, and agreement: The morphosyntax of inverse agreement and global case splits. Oxford: Oxford University Press.

Bartos, Huba. 2000. Az inflexiós jelenségek szintaktikai háttere. In Ferenc Kiefer (ed.), Strukturális magyar nyelvtan. 3. Morfológia, 653-762. Budapest: Akadémiai Kiadó.

Béjar, Susana \& Milan Rezac. 2009. Cyclic agree. Linguistic Inquiry 40(1). 35-73. https: //doi.org/10.1162/ling.2009.40.1.35.

Bobaljik, Jonathan. 2000. The ins and outs of contextual allomorphy. University of Maryland Working Papers in Linguistics 10. 35-71.

Chomsky, Noam. 1995. The Minimalist program. Cambridge, MA: MIT Press.

Chomsky, Noam. 2000. Minimalist inquiries: The framework. In Roger Martin, David Michaels \& Juan Uriagereka (eds.), Step by step: Essays on Minimalist syntax in honor of Howard Lasnik, 89-155. Cambridge, MA: MIT Press.

Chomsky, Noam. 2001. Derivation by phase. In Michael Kenstowicz (ed.), Ken Hale: A life in language, 1-52. Cambridge, MA: MIT Press.

Csirmaz, Aniko. 2008. Particles and a two component theory of aspect. In Katalin É. Kiss (ed.), Event structure and the left periphery, 107-128. Dordrecht: Springer. 
Dalmi, Gréte. 2005. The role of agreement in non-finite predication. Amsterdam: John Benjamins. den Dikken, Marcel. 2018. An integrated perspective on Hungarian nominal and verbal inflection. In Huba Bartos, Marcel den Dikken, Zoltán Bánréti \& Tamás Váradi (eds.), Boundaries crossed, at the interfaces of morphosyntax, phonology, pragmatics and semantics, 147162. Cham: Springer.

É. Kiss, Katalin. 2002. The syntax of Hungarian. Cambridge: Cambridge University Press.

É. Kiss, Katalin. 2008a. Free word order, (non)configurationality, and phases. Linguistic Inquiry 39(3). 441-475. https://doi.org/10.1162/ling.2008.39.3.441.

É. Kiss, Katalin. 2008b. From the grammaticalization of viewpoint aspect to the grammaticalization of situation aspect. In Katalin É. Kiss (ed.), Event structure and the left periphery, 129-157. Dordrecht: Springer.

É. Kiss, Katalin. 2008c. The function and the syntax of the verbal particle. In Katalin É. Kiss (ed.), Event structure and the left periphery, 17-55. Dordrecht: Springer.

É. Kiss, Katalin. 2017. The rise and fall of Hungarian complex tenses. In Eric Mathieu \& Robert Truswell (eds.), Micro-change and macro-change in diachronic syntax, 61-74. Oxford: Oxford University Press.

Embick, David. 2015. The morpheme: A theoretical introduction. Berlin: de Gruyter.

Embick, David \& Rolf Noyer. 2001. Movement operations after syntax. Linguistic Inquiry 32(4). 555-595. https://doi.org/10.1162/002438901753373005.

Halle, Morris \& Alec Marantz. 1993. Distributed morphology and the pieces of inflection. In Kenneth Hale \& Samuel Jay Keyser (eds.), The view from Building 20: Essays in linguistics in honor of Sylvain Bromberger, 111-176. Cambridge, MA: MIT Press.

Harley, Heidi \& Elizabeth Ritter. 2002. Person and number in pronouns: A feature-geometric analysis. Language 78(3). 482-526. https://doi.org/10.1353/lan.2002.0158.

Keresztes, Júlia. 2014. Object-drop in Hungarian. Wiener Linguistische Gazette 78A. 148-165.

Pesetsky, David \& Esther Torrego. 2007. The syntax of valuation and the interpretability of features. In Simin Karimi, Vida Samiian \& Wendy Wilkins (eds.), Phrasal and clausal architecture: Syntactic derivation and interpretation, 262-294. Amsterdam: John Benjamins.

Preminger, Omer. 2014. Agreement and its failures. Cambridge, MA: MIT Press.

Richards, Marc. 2012. Probing the past: On reconciling long-distance agreement with the PIC. In Artemis Alexiadou, Tibor Kiss \& Gereon Müller (eds.), Local modelling of non-local dependencies in syntax, 135-154. Berlin: de Gruyter.

Ruda, Marta. 2017. On the syntax of missing objects: A study with special reference to English, Polish, and Hungarian. Amsterdam: John Benjamins.

Szécsényi, Krisztina. 2009. On the double nature of Hungarian infinitival constructions. Lingua 119(4). 592-624. https://doi.org/10.1016/j.lingua.2007.11.005.

Szécsényi, Krisztina \& Tibor Szécsényi. 2017. Definiteness agreement in Hungarian multiple infinitival constructions. In Joseph Emonds \& Markéta Janebová (eds.), Language use and linguistic structure: Proceedings of the Olomouc Linguistics Colloquium 2016, 75-89. Olomouc: Palacký University.

Travis, Lisa. 2000. The L-syntax/S-syntax boundary: Evidence from Austronesian. In Ileana Paul, Vivianne Phillips \& Lisa Travis (eds.), Formal issues in Austronesian syntax, 167194. Dordrecht: Springer.

Trommer, Jochen. 2005. Hungarian has no portmanteau agreement. In Péter Siptár \& Christopher Piñon (eds.), Approaches to Hungarian 9, 285-302. Budapest: Akadémiai Kiadó. 